\title{
О СМОЛЕ, ВОЗНИКАЮЩЕЙ В ПРОЦЕССЕ САМОВОЗГОРАНИЯ ДИКТИОНЕМОВОГО ГОРЮЧЕГО СЛАНЦА. 3. СОСТАВ СМОЛЫ МЕДЛЕННОГО ГОРЕНИЯ
}

I. KLESMENT, MARET KUUSIK. ISESUTTINUD DIKTUONEEMAKILDA OLIERITUSEST, 3. AEG. LASEL POLEMISEL MOODUSTUVA OLI KOOSTIS

I. KLESMENT, MARET KUUSIK. ON THE OIL FORMED BY SELF-IGNITION OF DICTYONEMA OIL SHALE. 3. THE COMPOSITION OF SLOW COMBUSTION OIL

\section{(Представил О. Эйзен)}

Проблемы самовозгорания обсуждаются в сообщении ['], где и представлен литературный обзор ранее проделанных работ. Пробы для настоящей работы были взяты весной 1978 года у подножия горящего отвала диктионемового сланца, удаленного в процессе карьерной добычи фосфорита месторождения Маарду. На месте отбора проб (в отличие от [']) не было интенсивного движения газообразных продуктов горения и термической деструкции изнутри отвала к его поверхности, температура верхнего слоя отвала лишь незначительно превышала температуру окружающего воздуха. С увеличением глубины в отвале резко повышалась температура.

Характеристика проб диктионемового сланца и продуктов его термического разложения в результате самовозгорания отвала сланца

\begin{tabular}{|c|c|c|c|c|}
\hline \multirow{2}{*}{ Показатели } & \multirow{2}{*}{$\begin{array}{c}\text { Сырой } \\
\text { сланец }\end{array}$} & \multicolumn{3}{|c|}{ Степень термического превращения } \\
\hline & & низкая & средняя & высокая \\
\hline Глубина взятия пробы, см & - & $0-15$ & $20-30$ & $40-50$ \\
\hline Температура в отвале, ${ }^{\circ} \mathrm{C}$ & - & $50-100$ & $150-250$ & 300 \\
\hline Содержание ОВ в сланце, \% & 16,2 & 18,8 & 14,2 & 9,4 \\
\hline Содержание смолы в ОВ, \% & 2,4 & 3,9 & 10,2 & 0,7 \\
\hline Групповой состав смолы, вес. $\%$ : & & & & \\
\hline cepa & 12,1 & 23,9 & 6,7 & 13,0 \\
\hline нейтральная смола & 32,9 & 38,1 & $50 ; 1$ & 51,2 \\
\hline жирные кислоты & 38,0 & 24,6 & 28,6 & $\begin{array}{r}35,1 \\
0\end{array}$ \\
\hline высокомолекулярные кислоты & 12,2 & 12,2 & 8,5 & 0,8 \\
\hline $\begin{array}{l}\text { Групповой состав нейтральной смолы, } \\
\text { вес. \%: }\end{array}$ & & & & \\
\hline парафины & 10,5 & 18,8 & 18,4 & 51,8 \\
\hline алкилбензолы & 8,9 & 7,8 & 8,3 & 13,4 \\
\hline $\begin{array}{l}\text { полициклические ароматические } \\
\text { соединения }\end{array}$ & 21,6 & 22,3 & 31,3 & 11,7 \\
\hline малополярные гетеросоединения & 9,0 & 11,1 & 13,3 & 5,8 \\
\hline сильнополярные гетеросоединения & 40,3 & 40,0 & 13,7 & 17,3 \\
\hline
\end{tabular}




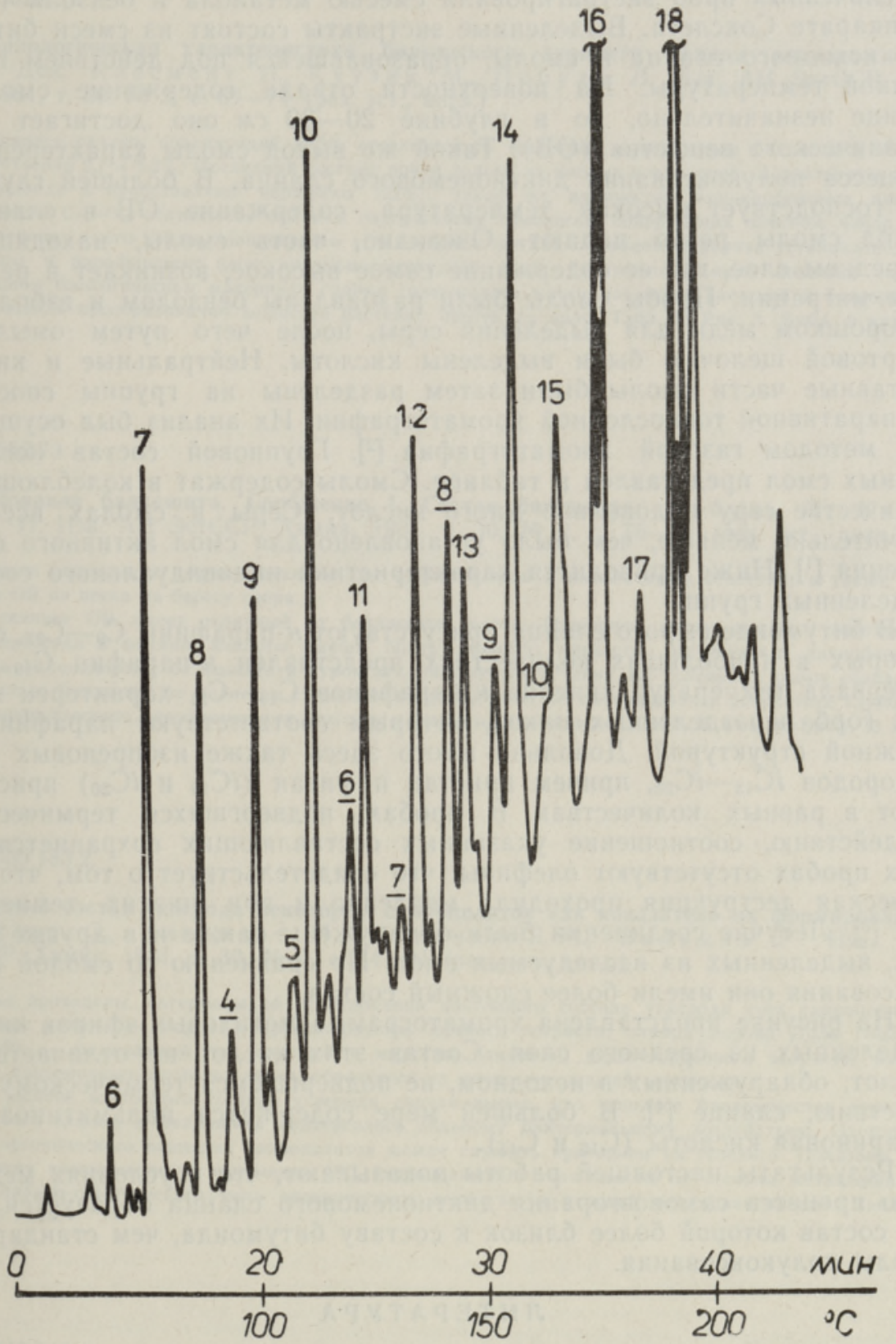

Хроматограмма метиловых эфиров жирных кислот, выделенных из битумоида среднего слоя. Номера означают количество углеродных атомов в кислотах. Подштрихованные пики соответствуют двуосновным кислотам. Колонка $1 \times 3$ мм, 1,6\% LAC 2-R-446 на хезасорбе AW $(0,20-0,25$ мм).

Данные о местах взятия проб и составе смол, выделенных из указанных проб, представлены в таблице. Были взяты три пробы с разных глубин, а также с целью сравнения - проба сырого, не подвергшегося изменению сланца. В глубине 0,5 м от поверхности отвала температура приближается к обычным температурам полукоксования. Смолу из 
измельченных проб экстрагировали смесью метанола и бензола $(1: 3)$ в аппарате Сокслета. Выделенные экстракты состоят из смеси битумоида исходного сланца и смолы, образовавшейся под действием повышенной температуры. На поверхности отвала содержание смолы в сланце незначительно, но в глубине $20-30$ см оно достигает $10 \%$ органического вещества (ОВ). Такой же выход смолы характерен для процесса полукоксования диктионемового сланца. В большей глубине, где господствует высокая температура, содержание ОВ в сланце и выход смолы резко падают. Очевидно, часть смолы, находящейся в среднем слое, где ее содержание самое высокое, возникает в результате миграции. Пробы смолы были разбавлены бензолом и взболтаны с порошком меди для выделения серы, после чего путем омыления спиртовой щелочью были выделены кислоты. Нейтральные и кислые составные части смолы были затем разделены на группы способом препаративной тонкослойной хроматографии. Их анализ был осуществлен методом газовой хроматографии [2]. Групповой состав исследованных смол представлен в таблице. Смолы содержат в колеблющемся количестве серу и довольно много кислот. Серы в смолах все-таки значительно меньше, чем было установлено для смол активного очага горения [ $\left.{ }^{1}\right]$. Ниже приводится характеристика индивидуального состава выделенных групп.

В битумоиде сырого сланца присутствуют $\boldsymbol{H}$-парафины $\mathrm{C}_{9}-\mathrm{C}_{27}$, среди которых в наибольших количествах представлен $H$-парафин $\mathrm{C}_{19}$. Для интервала температур кипения н-парафинов $\mathrm{C}_{19}-\mathrm{C}_{21}$ характерен высокий горб неразделенных пиков, которым соответствуют парафины со сложной структурой. Довольно много здесь также изопреновых углеводородов $i \mathrm{C}_{13}-i \mathrm{C}_{20}$, причем пристан и фитан $\left(i \mathrm{C}_{19}\right.$ и $\left.i \mathrm{C}_{20}\right)$ присутствуют в равных количествах. В пробах, подвергшихся термическому воздействию, соотношение указанных составляющих сохраняется. Во всех пробах отсутствуют олефины, что свидетельствует о том, что термическая деструкция проходила медленно и при низких температуpax [3]. Летучие соединения были обнаружены также и в других группах, выделенных из исследуемых смол. По сравнению со смолой полукоксования они имели более сложный состав.

На рисунке представлена хроматограмма метиловых эфиров кислот, выделенных из среднего слоя. Состав этих кислот не отличается от кислот, обнаруженных в исходном, не подвергшемся термическому воздействию, сланце [4]. В большей мере содержатся пальмитиновая и стеариновая кислоты $\left(\mathrm{C}_{16}\right.$ и $\left.\mathrm{C}_{18}\right)$.

Результаты настоящей работы показывают, что в условиях медленного процесса самовозгорания диктионемового сланца образуется смола, состав которой более близок к составу битумоида, чем стандартной смолы полукоксования.

\section{ЛИТЕ РА Т У РА}

1. В ески Р., Сидоров а С. О смоле самовозгорания диктионемового сланца 1. Сера в смоле. - Изв. АН ЭССР. Хим., 1981, т. 30, № 2, с. $95-100$.

2. Kles ment, I. Application of chromatographic methods in biogeochemical investigations. - J. Chromatogr., 1974, v. 91, N 1, p. 705-713.

3. У ров К. Э., Клесмен т И. Р. Превращение кукерсита при медленном термолизе в породных отвалах. - Изв. АН СССР. Сер. геол., 1974, № 6, с. 121124.

4. Бондарь Е., Вески Р. Ненасыщенные жирные кислоты в битумоиде ордовикского диктионемового сланца. - Изв. АН ЭССР. Хим., 1980, т. 29, № 4, c. $251-255$. 